\section{Can accounting-based and market-based indicators predict changes in the risk rating of brazilian banks?}

\author{
Ronaldo Trapiá Garcia ${ }^{1}$ \\ Danilo Soares Monte-Mor ${ }^{1}$ \\ Neyla Tardin ${ }^{1}$ \\ ${ }^{1}$ Fucape Business School, Vitória-ES, Brazil
}

Received on:

03/29/2016

Approved on:

08/09/2018

Responsible Editor:

Prof. Dr. Eduardo Contani

Evaluation process:

Double Blind Review

\begin{abstract}
Purpose - This work aims to analyze whether market indicators, in complementarity to accounting indicators, have the ability to anticipate changes (upgrades or downgrades) in the assessments of risk rating (rating) of banks in Brazil.
\end{abstract}

Design/methodology/approach - We used information based on the merger of two databases, Economatica and Standard \& Poor's/Fitch, from 2010 to 2014, and linear regressions based on probit models.

Findings - Our results show that market-based indicators as Sovereign Risk and GDP growth, together with accounting-based indicators as asset quality, liquidity, risk, capital and profitability, have predictive power for risk rating changes of banks in Brazil. The results still show that the market did not price changes in Brazilian banks' ratings in windows ending in the event date. Such evidence suggest that Sovereign Risk and economic-systemic factors can be used to proxy for risk in volatile markets with high uncertainty.

Originality/value - Unlike in developed countries, the Brazilian stock market, young and not very representative of the economy, was not able to anticipate changes in the banks' rating. This study anticipates information to investors who aid in the decision to buy, hold or sell securities, and signals that the financial system is more susceptible to macroeconomic shocks in unstable economies.

Keywords - Rating; Accounting Indicators; Market Indicators, Banking Industry.

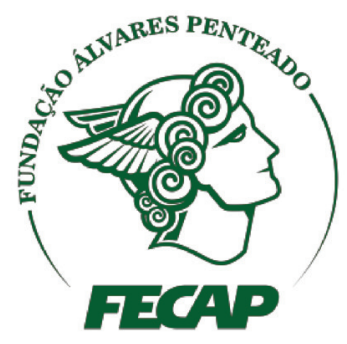

Review of Business Management

DOI:10.7819/rbgn.v21i1.3968 


\section{Introduction}

Ratings are an analysis tool of the financial market that allow companies and investors to qualify countries, economic areas, and companies, and to measure investment risks (Shen, Huang, $\&$ Hasan, 2012; Distinguin, Hasan, \& Tarazi, 2013; Ioana, 2014). It is difficult for a big company or country to secure credit with investors before being assessed by a risk rating agency regarding its capacity to comply with its commitments (Adams, Burton, \& Hardwick, 2003; Papaioannou, 2011). Specifically for the financial market, ratings are very important for banks because, according to Murcia, Dal-Ri Murcia, Rover, and Borba (2014), the cost of debt of new loans and financing is more expensive when their risk ratings are downgraded.

Several studies recommend the auxiliary use of market indicators to predict an upgrading or downgrading in the rating of a bank (Berger, Davies, \& Flannery, 2000; Curry, Fissel, \& Hanweck, 2008). In general, these studies show that market data such as stock returns substantially improve the predictive ability of models based entirely on accounting data (Krainer \& Lopez, 2004; Adelino \& Ferreira, 2016; Moody's, 2016). According to the literature, risk rating agencies state that other market indicators such as sovereign risk also tend to influence banks, especially regarding fundraising sources and stock and security prices (Acharya, Drecshler, \& Schnabl, 2014; Adelino \& Ferreira, 2016; Moody's, 2016).

However, in emergent markets, most of the studies on predicting bankruptcy mainly focus on crisis alerts regarding the whole financial system, in particular after the financial crisis of 1997 (Demirgüç-Kunt \& Detragiache, 2000; Distinguin, Hasan, \& Tarazi, 2013; Sanfins \& Monte-Mor, 2014). In other words, such studies focus on analyzing systemic crises and not on the financial health of individual banks, especially within the scope of the regulatory framework implemented by the Basel Committee on Banking Supervision and the Basel III Agreement (Distinguin, Hasan, \& Tarazi, 2013).
In Brazil, specifically, there are no models that relate market-based and accounting-based indicators to changes in the risk ratings of banks. There are only studies about predicting bankruptcy based on analyses that use the Z-Score model developed by Altman (1968), which was created to measure insolvency risks but only takes into consideration accounting-based indicators that do not contain probability aspects and uses random criteria when gathering normal variables (Murcia et al., 2014).

This paper aims to analyze if market-based indicators, as a complement to accounting-based indicators, can anticipate changes in the risk ratings of banks in Brazil. The discussion should contribute empirically to the literature regarding ratings changes in banks within countries with volatile financial markets subject to political and economical uncertainties and regular changes to their sovereign risk ratings, such as the Brazilian market.

Between 2006 and 2016, Brazil achieved investment grade, considerably affecting foreign direct investment, but lately its credit grade has been continuously downgraded back to a speculative grade rating (Standard \& Poor's, 2016). Also, the country has faced an economic crisis linked to political and financial instability, as well as company failures, including banks. Such movements can change the ratings dynamics of financial institutions (Adelino \& Ferreira, 2016).

The specifics of the Brazilian financial market also warrant empirical research, since it has different characteristics from the developed countries where similar studies have been carried out. For example, Brazil has a smaller stock market, companies with concentrated control, big banks directly controlled by the federal government, and rigid regulation (Murcia et al., 2014).

According to the results found by Distinguin, Hasan, and Tarazi, (2013), who state that for Asian banks accounting-based indicators together with indicators resulting from market price can affect the probability of upgrades and downgrades being issued by risk rating agencies, 
market-data indicators together with accountingbased indicators are expected to predict changes issued by the credit rating agencies (CRAs) to the banks in Brazil.

To enable the analysis of whether marketbased indicators, together with accounting-based indicators, can anticipate changes in the ratings of banks in Brazil, the probit model was applied to 13 banks listed on the BM\&F Bovespa from 2010 to 2014. This study follows other studies: Curry, Fissel, and Hanweck (2008), who tried to find downgradings in USA banks; Gropp, Vesala, and Vulpes (2006), who tried to predict bankruptcy in European banks; and the study by Distinguin, Hasan, and Tarazi, (2013), who predicted ratings changes for Asian banks.

In this study, the accounting-based indicators were divided into four (4) groups: Asset Quality; Liquidity; Capital and Profitability; and Risk, as in the methodology used by the rating agencies Moody's (2016), Fitch (2015), and Standard and Poor's (2011). The marketbased indicators were the banks' market prices (Distinguin, Hasan, \& Tarazi, 2013), GDP growth (Gande \& Parsley, 2014; Acharya, Drecshler, \& Schnabl, 2014), and sovereign ratings changes (Adelino \& Ferreira, 2016).

This study assesses the use of marketbased indicators such as sovereign risk, market return, and economic-systemic factors as signals of risk in volatile and insecure markets. The study is important for three groups: for investors, according to Papaioannou (2011), the research anticipates information that helps in the decision to purchase, keep, or sell bonds; for banks, it is important to present information that can justify increasing or decreasing the interest rate of creditors (Gullo, 2014); and, finally, for creditors, it is important because it can predict changes to companies' credit risks (Ioana, 2014). Besides influencing investment, ratings changes can affect the future value of stocks and the cost of fundraising ( $\mathrm{Li}$ et al., 2008), as well as debt structure and market value (Murcia et al., 2014).

Especially for the financial market, ratings are very important to banks because, according to Murcia et al. (2014), the cost of new loans and financing is more expensive when their risk ratings are downgraded. In the last version of the Basel agreement, Basel III, the world's concern about the possibility of bank insolvency is clear, because the focus of the changes is divided into three points: leverage limits, required liquidity percentages, and discussions about pro-cyclicity (Braslins \& Arefjevs, 2013). Since Brazil already has rigid regulations regarding banks and adopts the Basel III recommendations, there is great interest in checking the main factors that determine ratings (Pinheiro, Savóia, \& Securato, 2015).

\section{Theoretical References}

\section{I Ratings and the Credit Rating Agencies (CRAs)}

The risk rating system is a process that involves analyzing the financial strength and risk exposure of companies/countries (Moody's, 2016; Fitch, 2015; Standard \& Poor's, 2011). In 2015, the three biggest international rating companies were Fitch, Moody's, and Standard \& Poor's (Distinguin, Hasan, \& Tarazi, 2013). According to Gaillard (2014), to develop ratings, the agencies (CRAs) visit the companies and countries assessed in order to discuss financial and operational plans and performance strategies among all participants.

To rank a country as investment grade, at least two of these three companies need to consider it a good payer; otherwise the country is ranked in the speculation group (Gaillard, 2014). According to Murcia et al. (2014), it is hard for a company to be granted investors' credit without being assessed by one of these rating companies regarding its ability to pay debts. The authors also emphasize that the interest rates charged for loans and financing are directly connected to this rating. 


\begin{tabular}{|c|c|c|c|c|}
\hline \multicolumn{5}{|c|}{ RANKING OF THE RISK RATING AGENCIES } \\
\hline \multirow{2}{*}{ Fitch Ratings } & \multirow{2}{*}{$\begin{array}{l}\text { Standard \& Poor's } \\
\text { AAA }\end{array}$} & \multirow{2}{*}{\begin{tabular}{|l} 
Moody's \\
Aaa \\
\end{tabular}} & \multicolumn{2}{|c|}{ Meaning on the scale } \\
\hline & & & \multirow{7}{*}{$\hat{9}$} & \multirow{7}{*}{$\begin{array}{l}\text { Investment grade with } \\
\text { high quality and low risk }\end{array}$} \\
\hline $\mathbf{A A}+$ & $\mathbf{A A}+$ & Aa1 & & \\
\hline $\mathbf{A A}$ & AA & Aa2 & & \\
\hline AA- & AA- & Aa3 & & \\
\hline A+ & $\mathbf{A}+$ & A1 & & \\
\hline A & A & A2 & & \\
\hline A- & A- & A3 & & \\
\hline BBB + & BBB + & Baa1 & & \\
\hline BBB & BBB & Baa2 & & $\begin{array}{l}\text { Investment grade, } \\
\text { average auality }\end{array}$ \\
\hline BBB- & BBB- & Baa3 & & \\
\hline BB+ + & BB+ & Ba1 & & \\
\hline BB & BB & Ba2 & & \\
\hline BB- & BB- & Ba3 & & Speculation Grade, \\
\hline B+ & B+ & B1 & & low rating. \\
\hline B & B & B2 & & \\
\hline B- & B- & B3 & & \\
\hline $\mathrm{CCC}$ & $\mathrm{CCC}+$ & Caa1 & & \\
\hline $\mathrm{CC}$ & $\mathrm{CCC}$ & Caa2 & & \\
\hline $\mathbf{C}$ & CCC- & Caa3 & & High risk of default \\
\hline RD & $\mathrm{CC}$ & $\mathbf{C a}$ & & and low interest. \\
\hline D & $\mathrm{C}$ & $\mathrm{C}$ & & \\
\hline & D & & & \\
\hline
\end{tabular}

Picture 1. Ratings Scale.

Source: Elaborated by the author.

Picture 1 shows the risk ratings used by each one of the three agencies. We can notice that, despite some differences regarding names, the pattern of risk assessment is similar. The scales are divided into four blocks of risk. The higher level is investment grade with high quality and low risk. The countries and companies within the first and second level groups are considered good payers and have a lower possibility of failure (Ioana, 2014). In the third group, the companies and nations are rated as speculation level and are considered bad payers. In this group, there is a risk of failure so the fees paid to investors are high (Hill, 2004). These ratings are important for the Basel III Agreement and our next section describes the implementation of the agreement in Brazil.

\subsection{Accounting and market indicators}

According to Standard \& Poor's (2009), to determine ratings, the possibility of default is the most relevant dimension in credit quality and in the definitions of risk rating we assign a high importance to probability of default.

Besides probability of default, some secondary items of credit quality are taken into consideration: payment priority, credit recovery, and stability; and these can become important elements when applying the ratings definitions to the development of criteria for the specific situations of banks (Standard \& Poor's, 2009). The main accounting ratio used to analyze financial institutions is divided into four groups: 
Asset Quality; Liquidity; Capital and Profitability; and Risk (Moody's, 2016; Fitch, 2015; Standard \& Poor's, 2011).

The first group, Asset Quality, has some impact on the rating because, according to Fitch's methodology (2015), most bank assets are calculated as amortized cost minus allowance for losses so assets with low performance can negatively affect bank capital. Thus, it is considered that high concentrations, geographically speaking, by product or customer segment, expose banks to risks and will probably be negative factors for ratings. Therefore, the CRA's focus is to determine if bank capital would probably be negatively affected due to inappropriate coverage levels by reserves.

In the second group, Liquidity, the rating is negatively affected by liquidity when the bank is overly dependent on the central bank of the country for fundraising. But strong liquidity in a specific time does not assure a high rating, since this item is assessed over several periods (Moody's, 2016; Fitch, 2015; Standard \& Poor's, 2011). For the Capital and Profitability group, Fitch (2015) emphasizes that a bank's result not being sustainable in the long term is a negative point in terms of rating (Moody's, 2016; Fitch, 2015; Standard \& Poor's, 2011). The Risk group involves the bank's level of risk, which is an important concern when attributing a rating. Its assessment verifies if the profit and growth targets correspond to the established level of risk.

Market indicators, according to Gropp, Vesala, and Vulpes (2006), can predict downgrades by risk rating agencies. The authors used as market indicators the market price indexes for European banks over long periods. Variables such as the difference between the natural logarithm of the market price and its moving average, cumulative return, and unusual cumulative returns can capture the effects of shocks or the presence of unusual returns (Distinguin, Hasan, \& Tarazi, 2013).

Another market indicator is sovereign risk, which involves the country's rating and is of great importance to the methodology for risk rating banks (Moody's, 2016; Fitch, 2015; Standard \& Poor's, 2011). The global financial crisis in 2008 revealed the close relationship between sovereign credit risk and the banking sector, according to Correa, Lee, Sapriza, and Suarez. (2014). The authors noticed that sovereign credit risk can affect banks in three ways. First, the fiscal situation of a government might directly affect domestic economic activity, which in turn affects the demand for financial services. For example, a tax increase might reduce investment and consumption, driving the demand for loans. Also, banks around the world tend to have substantial amounts of domestic public debt in their portfolios. Finally, governments are usually willing to support banks in order to avoid their failure, especially banks considered as "too big to go bankrupt" or systematically important ones. Also, a sovereign rating downgrade casts doubt upon the capacity of the government to avoid bankruptcy.

\subsection{Ratings vs. accounting and market indicators}

In general, studies performed in the USA show significant dependency of the risk ratings issued by CRAs on accounting and market indicators. One of the first studies in the area was carried out by Horrigan (1966). Integrating six financial variables present on Moody's methodology, the results showed around 58\% accuracy for the ratings issued by this CRA for big companies in the USA and approximately $52 \%$ for the S\&P ratings (Shen et al., 2012). Besides noticing a positive relationship, Pogue and Soldofsky (1969) and West (1970) changed the CRA scales that use letter sets into numeric scales for risk ratings and reverted these numbers into accounting data and other market variables such as bond market price as an explanatory variable, enhancing the accuracy in predicting Moody's ratings from $58 \%$ to $62 \%$ (Blume, Lim, \& Mackinlay, 1998). 
Following this framework, Pinches and Mingo (1973) and Altman and Katz (1976) used discriminatory analysis instead of regression analysis to relate the scales with company data. Kaplan and Urwitz (1979) used the ordered Probit model and concluded that available public data can predict ratings with reasonable accuracy (Blume, Lim, \& Mackinlay, 1998).

Recent studies have also shown that, besides accounting data, market data have a strong influence in determining ratings. For example, Blume, Lim, and Mackinlay (1998) noticed that accounting and market risk data were determinant variables for big companies' ratings. Likewise, Estrella (2000) observed the predictive power of the capital indexes of American bankruptcies and found a strong connection between the capital indexes and ratings assessments, in that balance sheet and size data could reproduce most of S\&P's ratings (Shen et al., 2012).

Other studies, such as that of DemirgüçKunt and Huizinga (2013), present evidence that changes in sovereign ratings might affect the market value of public and private banks and the effect is more sensitive for banks that are supported by the government.

In Brazil, though, there were no models relating market and accounting indicators to predictions of changes in the risk ratings of banks. Based on the results found by Gropp, Vesala, and Vulpes (2006), who stated that, for European banks, market price indicators can predict downgrades issued by CRAs for a reasonable period of time; and by Curry, Fissel, and Hanweck (2008), who concluded that stock market variables can provide appropriate information and add value to the accounting models that predict ratings changes, to upgrade or downgrade American banks; among the other discussions in the previous subsection, we present the following hypothesis:

H1: Market indicators can predict changes made by the risk rating agencies in Brazil.

\section{Procedures to Select the Sample and Empirical Design}

To carry out this research, we used information gathered from a merger of two databases, Economática and Standard \& Poor's/ Fitch, covering 2010 to 2014. From Economática we extracted financial and accounting indicators as well as data about market return. The data collection involving ratings changes in the banks was performed using publications and reports issued by S\&P and Fitch. Consolidating the two databases resulted in a list of thirteen (13) banks that have stocks listed on the BM\&F Bovespa and that are in the group of the thirtyfive (35) biggest banks presented in the report "Top Brazilian Banks", released by Standard \& Poor's in June, 2014.

As the research hypothesis is related to using market indicators together with accounting indicators as predictors of ratings changes, only banks listed on the BM\&F Bovespa could be used. Banks such Caixa Econômica Federal S.A., Banco Nacional de Desenvolvimento Econômico e Social - BNDES, HSBC Bank Brasil S.A, Banco Safra S.A, and Banco Votorantim S.A were not taken into consideration because they did not have stocks listed on the BM\&F Bovespa within the period analyzed and it was not possible to calculate their cumulative returns (one of the market indicators used).

Although the range of the research is limited to listed banks and does not allow for direct inferences regarding banks that are not listed, it is important to emphasize that among the banks in the sample there five (5) of the ten (10) biggest banks in Brazil, four (4) banks from among the 11 th to 20th biggest, and four (4) banks from among the 21 st to 35 th biggest. Thus, the thirteen (13) biggest banks listed are from among the thirty-five (35) biggest Brazilian banks, as according to data from $12 / 31 / 2013$, which assures a certain level of diversity in the sample regarding the area. Besides, the banks used have, jointly, almost $60 \%$ of the market share of the sector, as according to Table 1. 
Table 1

Banks selected for the research

\begin{tabular}{|l|l|c|c|}
\hline Ranking & Bank & Total Assets & \% of market \\
\hline 1 & Banco do Brasil S.A & $1,218,525,361$ & 18.55 \\
\hline 2 & Itaú Unibanco Holding S.A & $1,027,324,008$ & 15.64 \\
\hline 4 & Banco Bradesco S.A & $776,724,294$ & 11.83 \\
\hline 6 & Banco Santander (Brasil) S.A & $495,443,913$ & 7.54 \\
\hline 9 & Banco BTG Pactual S.A & $115,901,631$ & 1.76 \\
\hline 11 & Banco Citibank S.A & $54,297,355$ & 0.83 \\
\hline 12 & Banco do Estado do Rio Grande do Sul S.A - BANRISUL & $53,114,488$ & 0.81 \\
\hline 17 & Panamericano S.A & $21,725,860$ & 0.33 \\
\hline 20 & Banco ABC Brasil S.A & $17,267,769$ & 0.26 \\
\hline 21 & Banco Industrial e Comercial S.A & $15,606,886$ & 0.24 \\
\hline 23 & Banco Daycoval S.A & $14,940,278$ & 0.23 \\
\hline 26 & Banco Mercantil do Brasil S.A & $13,510,309$ & 0.21 \\
\hline 32 & Banco Pine S.A & $10,558,749$ & 0.16 \\
\hline & & $\%$ of Assets in the Brazilian market & 58.39 \\
\hline
\end{tabular}

Source: Standard \& Poor's, 2014, p. 51.

The data analysis was performed from 2010 onward, since the requirements for banks in Brazil to disclose their financial statements according to IFRS (International Financial Reporting Standards) came into effect that year. Using IFRS simplifies the comparison between banks and leads to greater transparency, especially regarding some aspects of financial health (Firoz, Ansari, \& Akhtar, 2011).

\section{I Empirical data and the Probit model}

To verify if the market indicators, as a complement to the accounting indicators, can predict changes in risk rating assessments (downgrades or upgrades), related to rating maintenance, the Probit model was chosen as in equation 1.

$$
\begin{aligned}
\text { ChangeRating }_{\text {it }}= & \beta_{1} \text { AssetQuality }_{\text {it }-1}+\beta_{2} \text { Liquidity }_{\text {it }-1} \\
+ & \beta_{3} \text { Capital and Profitability }_{\mathrm{it}-1}+\beta_{4} \text { Risk }_{\mathrm{it}-1}+\beta_{5} \text { CumulativeReturn }_{\mathrm{it}} \\
& +\beta_{6} \text { SovereignRisk }_{\mathrm{it}}+\beta_{7} \text { GDPGrowth }_{\mathrm{it}}+\varepsilon_{\mathrm{it}}
\end{aligned}
$$

At first, model 1 was estimated by comparing the upgrade scenario with rating maintenance and, then, by comparing the downgrade scenario with rating maintenance. This means that, in each case, there is a comparison between the rating change scenario and stability, where there is no change in the bank's rating. Therefore:
- in a first analysis, the variable takes the value 1 if the rating of bank i receives an upgrade (by Fitch or Standard \& Poor's); and 0 when the agencies decided to maintain the risk rating the same as the previous one;

- similarly, in a second analysis, the variable takes the value 1 if the rating of the 
bank receives a downgrade (by Fitch or Standard \& Poor's); and 0 when the agencies decided to maintain the risk rating the same as the previous one;

Note that the choice of a binary model (division of the analysis into comparisons of upgrade vs. maintenance and downgrade vs. maintenance) rather than a multinomial model was motivated by the limited number of banks in the sample (characteristic of the Brazilian sector). In this regard, binary models, which require a lower number of interactions and make convergence of the associated probability function possible (Bourguignon, Fournier, \& Gurgand, 2007), allow us to assess if the market indicators, as a complement to the accounting indicators, can predict changes in the risk rating assessments (downgrades or upgrades) of Brazilian banks.

The accounting indicators (Capital Quality, Liquidity, Capital and Profitability, and Risk) and market indicators (Cumulative Return, Sovereign Risk, and GDP Growth) used as predictors of ratings changes in the banks are described in Table 2. Regarding the calculation of Cumulative Return, we considered three windows for anticipating the risk rating events: three (3) working days, five (5) working days, and thirty (30) working days before each event. The variable Sovereign Rating is a dummy that takes the value
1 if the rating of the country has changed in the windows of each analysis.

It is important to note that the design used in the research, by not considering the days after the release of the risk rating, is different from the design used in papers that analyze the effect of the events. This is because the objective here is to assess if the market indicators, as a complement to the accounting indicators, can predict changes in the risk rating assessments. In this case, the use of windows that might consider periods after the events would include noise, which means information after the disclosures.

Regarding the use of sovereign risk, Adelino and Ferreira (2016) present evidence that a downgrade in the country's credit rating not only affects fundraising and bank debt but also the value of stocks, which tend to have lower and more volatile returns. From this point of view, previous studies such as the one by Acharya, Drecshler, and Schnabl (2014) also noticed that the downgrading of the country's credit rating can affect the risk premium required on the credit operations of its financial institutions, especially when there is a downgrade. Also, in order to minimize possible systemic influences on ratings changes, a control was also included for GDP growth (Gande \& Parsley, 2014; Acharya, Drecshler, \& Schnabl, 2014). 
Table 2

Accounting and Market Indicators.

\begin{tabular}{|c|c|c|}
\hline GROUP & VARIABLES & DESCRIPTION OF THE GROUP \\
\hline \multicolumn{3}{|c|}{ ACCOUNTING INDICATORS } \\
\hline Asset Quality & $\begin{array}{l}\text { - Allowance for loan losses / } \\
\text { customer loans }\end{array}$ & $\begin{array}{l}\text { Asset quality measures the risks of the credit portfolio. High concentrations } \\
\text { expose the bank to risks. }\end{array}$ \\
\hline Liquidity & $\begin{array}{l}\text { - New customer loans / customer } \\
\text { deposits }\end{array}$ & $\begin{array}{l}\text { The liquidity analysis focuses on the ability of a bank to manage its } \\
\text { liquidity needs in difficult market and economic situations and its } \\
\text { probability of surviving for a long period under these conditions. }\end{array}$ \\
\hline $\begin{array}{l}\text { Capital and } \\
\text { Profitability }\end{array}$ & $\begin{array}{l}\text { - ROE (return on net equity) } \\
\text { - Adjusted net equity }\end{array}$ & $\begin{array}{l}\text { The profitability analysis offers an indication of a bank's ability to generate } \\
\text { returns from its main business lines. The absolute levels of the results } \\
\text { are an important factor because the numbers can indicate if the returns } \\
\text { are proportional to the risks taken by the bank and if they can provide } \\
\text { information about its structural profitability. When the traditional } \\
\text { profitability indicators are weaker than those of other direct competitors, } \\
\text { the quality of the profitability is low. }\end{array}$ \\
\hline Risk & - Customer credit growth & $\begin{array}{l}\text { The level of appetite for established risk is an important consideration } \\
\text { for ratings. Its assessment verifies if the profit and growth targets are } \\
\text { proportional to the level of established risk. }\end{array}$ \\
\hline \multicolumn{3}{|r|}{ MARKET INDICATORS } \\
\hline Market Return & $\begin{array}{l}\text { - Cumulative return; } \\
\text { - Sovereign risk; } \\
\text { - GDP growth }\end{array}$ & $\begin{array}{l}\text { Cumulative return was calculated as: } \\
\text { (stock price on the day of the event - stock price on a previous date) / stock } \\
\text { price on a previous date, and this date has to be } 3,5 \text {, or } 30 \text { working days } \\
\text { before the bank rating date. } \\
\text { Sovereign Risk is a dummy variable that indicates a ratings change in the } \\
\text { country issued by one of the two risk rating companies within } 3,5 \text {, or } 30 \\
\text { working days before the rating event. } \\
\text { GDP growth indicates the gross domestic product growth of the country in } \\
\text { real values. }\end{array}$ \\
\hline
\end{tabular}

Source: Elaborated by the author.

\section{Results}

\section{I Descriptive Statistics}

Table 3 presents the absolute and relative frequency of each change by the CRAs and the total number of changes within the period analyzed. It is possible to verify in Panel A of Table 3 that, within the period analyzed, Fitch was more conservative than S\&P when issuing ratings changes. During this period, Fitch made only one change in rating, which was a rating increase, while S\&P made 15 changes for the banks of the sample. The total number of the ratings changes was 10 downgrades and 6 upgrades, representing $12 \%$ and $7 \%$, respectively, of the total number of ratings issued by the two companies within the period. 
Table 3

Rating and Rating Perspective Changes for the Brazilian Banks

Panel A: Changes in Risk Rating

\begin{tabular}{lcccccc}
\hline & \multicolumn{2}{c}{ FITCH } & \multicolumn{2}{c}{ S\&P } & \multicolumn{2}{c}{ TOTAL } \\
\cline { 2 - 7 } & $\begin{array}{c}\text { No. } \\
\text { Obs. }\end{array}$ & Rel. Freq. & No. Obs. & Rel. Freq. & No. Obs. & Rel. Freq. \\
\hline Change - Downgrade & 0 & $0 \%$ & 10 & $18 \%$ & 10 & $12 \%$ \\
Change - Upgrade & 1 & $3 \%$ & 5 & $9 \%$ & 6 & $7 \%$ \\
Rating Confirmation & 28 & $97 \%$ & 41 & $73 \%$ & 69 & $81 \%$ \\
\hline Total Ratings Issued & $\mathbf{2 9}$ & $\mathbf{1 0 0} \%$ & $\mathbf{5 6}$ & $\mathbf{1 0 0} \%$ & $\mathbf{8 5}$ & $\mathbf{1 0 0} \%$ \\
\hline
\end{tabular}

Panel B: Changes in Risk Rating Perspective

\begin{tabular}{lcccccc}
\hline & \multicolumn{2}{c}{ FITCH } & \multicolumn{2}{c}{ S\&P } & \multicolumn{2}{c}{ TOTAL } \\
\cline { 2 - 7 } & $\begin{array}{c}\text { No. } \\
\text { Obs. }\end{array}$ & Rel. Freq. & No. Obs. & Rel. Freq. & No. Obs. & Rel. Freq. \\
\hline Change of Perspective - Positive & 3 & $10 \%$ & 5 & $9 \%$ & 8 & $9 \%$ \\
Change of Perspective - Negative & 1 & $3 \%$ & 19 & $34 \%$ & 20 & $24 \%$ \\
Stable Perspective & 25 & $86 \%$ & 32 & $57 \%$ & 57 & $67 \%$ \\
\hline Total Rating Perspectives & $\mathbf{2 9}$ & $\mathbf{1 0 0} \%$ & $\mathbf{5 6}$ & $\mathbf{1 0 0} \%$ & $\mathbf{8 5}$ & $\mathbf{1 0 0} \%$ \\
\hline
\end{tabular}

Source: Elaborated by the author.

Regarding changes of perspective, Panel $\mathrm{B}$ in Table 3 shows that S\&P also made more changes of perspective than Fitch. In total, Panel B presents eight (8) positive changes of perspective and twenty (20) negative ones out of 85 perspectives. Change of perspective is an important piece of data because it demonstrates a possible future rating change for the bank (Moody's, 2016; Fitch, 2015; Standard \& Poor's, 2011). Even if the information about rating demonstrates a stable perspective, the next disclosure might increase or decrease the rating without a previous review of the perspective since the context and analyses performed by the CRA ensure such action (Moody's, 2016; Fitch, 2015; Standard \& Poor's, 2011).
The descriptive statistics of the accounting indicators are represented in Table 4. These include the average, the standard deviation, and the median of each accounting indicator within the period analyzed. Table 4 presents an average level of $4.2 \%$ allowance for losses, which is considered as "acceptable" according to Fitch (2014). In addition, the average ROE was $14.1 \%$ within this period (Fitch, 2014), showing the high profitability of the segment. The nontabular results show an increasing growth in loans (18.5\%) between 2010 and 2014, which was possibly caused by the decrease in the interest rate charged by the banks within this period.

Table 4

Descriptive Statistics of the Accounting Indicators

\begin{tabular}{llccc}
\hline Accounting Indicator / Statistics & Average & Standard Deviation & Median \\
& New Customer Loans / Customer Deposits (\%) & 116.7 & 31.3 & 118.1 \\
& Return on Net Equity (\%) & 14.1 & 9.4 & 15.8 \\
\multirow{2}{*}{ TOTAL } & Adjusted Net Equity (in R\$ MM) & $28,188.0$ & $25,904.6$ & 2.0 \\
& Allowance for Loan Losses / & 4.2 & 20.2 & $11,569.3$ \\
& Customer Loans (\%) & 18.5 & 2.3 \\
\hline
\end{tabular}

Source: Elaborated by the author. 


\subsection{Results of the model}

Panels A and B in Table 5 show the results of model 1 for the scenario that compares rating upgrades for the banks with rating maintenance. Panels A and B consider the cumulative return and sovereign rating changes as market indicators for 3, 5, and 30 working days before the rating event, respectively. The results in Panel A show that there is no significant relationship between cumulative return and upgrade changes for these periods. These result are consistent with those of Gropp, Vesala, and Vulpes (2006), who stated that, for European banks, market price indicators can predict downgrades issued by CRAs within long periods; and Curry, Fissel, and Hanweck (2008), who concluded that stock market variables can provide appropriate information and add to the accounting models that predict ratings changes for upgrades and downgrades of American banks.

In this case, we can notice that, unlike in the European and American scenario, in windows previous to the banks' rating changes there is no average pricing of the rating changes in uncertain and volatile scenarios, such as in Brazil. This evidence is consistent with the results presented by Distinguin, Hasan, and Tarazi (2013) for Asian banks.

The results in Panel A of Table 5 also show that the indicators "New Customer Loans /Customer Deposits" and "Allowance for Loan Losses/Customer Loans" reduce the possibility of upgrades significantly, at $95 \%$ to $99 \%$ reliability. This is probably due to the fact that both indicators are connected to asset quality and bank liquidity. The higher these indicators, the lower the liquidity and, as a consequence, the probability of an upgrade change for the bank will be lower. This result was demonstrated in the study by Sinkey (1975), which emphasized asset quality and liquidity as good indicators for distinguishing banks with problems from banks with good financial health (Avkiran \& Cai, 2012).

The indicators "Return on Net Equity (ROE)" and "Adjusted Net Equity", significant at $99 \%$ and $95 \%$ respectively, in terms of reliability, demonstrate that the lower the Net Equity of the bank, the lower the probability of a rating upgrade (Lazarides \& Drimpetas,

2015). GDP growth, on the other hand, is significant at $99 \%$ reliability, highlighting the importance of the country's financial health to the credit risk rating of a bank (Moody's, 2016; Fitch, 2015, Standard \& Poor's, 2011). This can be explained because the higher the GDP growth of a country, the higher the possibility of the country and its banks' ratings increasing (Gaillard, 2014).

Regarding political and macroeconomic aspects, the literature shows that banks are intimately connected to their governments due to their dependency on domestic economic activity, which tends to not only affect government fiscal revenues but also revenues from private and public banks (Gropp, Vesala, \& Vulpes, 2006). As a consequence of this relationship, deterioration in the fiscal situation of the government can affect several financial elements, including funding for credit operations, default levels, savings account resources, and investment redemption, among others financial factors (Bolton \& Jeanne, 2011). However, as is shown in the analysis of the variable "Changes in Sovereign Risk or in Sovereign Risk Perspective" in Panel B of Table 5, an increase in rating or a positive rating perspective in the country does not present a significant relationship with upgrades in the banks for the 3, 5, and 30 days before the release issued by the CRAs. 
Table 5

Results of Model 1 for Scenario Upgrades vs Maintenance of the Bank's Rating

\begin{tabular}{|c|c|c|c|c|c|c|}
\hline \multicolumn{7}{|c|}{ Panel A: Estimate that uses Cumulative Return as a Market Indicator } \\
\hline \multirow[b]{2}{*}{ Indicators } & \multicolumn{2}{|c|}{3 DAYS } & \multicolumn{2}{|c|}{5 DAYS } & \multicolumn{2}{|c|}{30 DAYS } \\
\hline & Coefficients & $\mathbf{P}>|\mathbf{z}|$ & Coefficients & $\mathbf{P}>|\mathbf{z}|$ & Coefficients & $\mathrm{P}>|\mathrm{z}|$ \\
\hline Cumulative Return & -4.471 & 0.453 & -3.956 & 0.383 & 1.235 & 0.756 \\
\hline $\begin{array}{l}\text { New Customer Loans } \\
\text { / Customer Deposits }\end{array}$ & $-0.0474^{* *}$ & 0.028 & $-0.048^{* *}$ & 0.030 & $-0.047^{* *}$ & 0.015 \\
\hline $\begin{array}{l}\text { Return on Equity } \\
\text { (ROE) }\end{array}$ & $-0.147^{* * *}$ & 0.000 & $-0.153^{* * *}$ & 0.000 & $-0.156^{* * *}$ & 0.000 \\
\hline Adjusted Net Equity & $0.000028^{* *}$ & 0.048 & $0.000029^{* *}$ & 0.046 & $0.0000325^{* *}$ & 0.030 \\
\hline $\begin{array}{l}\text { Allowance for Loan } \\
\text { Losses / Customer } \\
\text { Loans }\end{array}$ & $-1.124^{* * *}$ & 0.001 & $-1.138^{* * *}$ & 0.001 & $-1.153^{* * *}$ & 0.000 \\
\hline $\begin{array}{l}\text { Growth of Customer } \\
\text { Credit }\end{array}$ & -0.021 & 0.400 & -0.021 & 0.414 & -0.023 & 0.461 \\
\hline GDP growth & $0.916^{* * *}$ & 0.001 & $0.915^{* * *}$ & 0.001 & $0.906^{* * *}$ & 0.000 \\
\hline N. Obs: & 75 & & 75 & & 75 & \\
\hline
\end{tabular}

Panel B: Estimate that uses changes in Sovereign Risk or in Sovereign Risk Perspective as a Market Indicator

\begin{tabular}{|c|c|c|c|c|c|c|}
\hline \multirow[b]{2}{*}{ Indicators } & \multicolumn{2}{|c|}{3 DAYS } & \multicolumn{2}{|c|}{5 DAYS } & \multicolumn{2}{|c|}{30 DAYS } \\
\hline & Coefficients & $\mathbf{P}>|\mathbf{z}|$ & Coefficients & $\mathbf{P}>|\mathbf{z}|$ & Coefficients & $P>|z|$ \\
\hline $\begin{array}{l}\text { Change in the Sovereign Risk or } \\
\text { in Sovereign Risk Perspective }\end{array}$ & 0.871 & 0.160 & 0.888 & 0.134 & 11.205 & 0.996 \\
\hline $\begin{array}{l}\text { New Customer Loans / Customer } \\
\text { Deposits }\end{array}$ & $-0.0509^{* * *}$ & 0.007 & $-0.048^{* *}$ & 0.014 & -0.181 & 0.997 \\
\hline Return on Equity (ROE) & $-0.190^{* * *}$ & 0.000 & $-0.187^{* * *}$ & 0.000 & -0.689 & 0.996 \\
\hline Adjusted Net Equity & $0.0000321^{* *}$ & 0.018 & $0.0000311^{* *}$ & 0.025 & 0.00007 & 0.999 \\
\hline $\begin{array}{l}\text { Allowance for Loan Losses / } \\
\text { Customer Loans }\end{array}$ & $-1.395^{* * *}$ & 0.002 & $-1.381^{* * *}$ & 0.001 & -5.345 & 0.996 \\
\hline Growth in Customer Credit & -0.017 & 0.465 & -0.022 & 0.491 & -0.495 & 0.997 \\
\hline GDP Growth & $0.978^{* * *}$ & 0.000 & $0.927^{* * *}$ & 0.000 & 2.867 & 0.997 \\
\hline N. Obs: & 75 & & 75 & & 75 & \\
\hline${ }^{* * *} \mathrm{p}<0.01,{ }^{* *} \mathrm{p}<0.05,{ }^{*} \mathrm{p}<0.1$ & & & & & & \\
\hline
\end{tabular}

Source: Elaborated by the author.

On the other hand, as we can notice in Panel B of Table 6, the indicator "Change in Sovereign Risk or in Sovereign Risk Perspective" is significant at $99 \%$ reliability for downgrading the rating. This result is consistent with that of Acharya, Drecshler, and Schnabl (2014), who observed that downgrades in the credit rating of the country result in negative returns on the stocks and bonds of public and private banks.

Other studies state that negative sovereign rating changes tend to impact the banking market particularly due to the fact that banks keep part of the domestic public debt in their portfolios (Kaminsky \& Schmukler, 2002; Gande \& Parsley, 2014). For Correa et al. (2014), among the existing transmission networks between sovereign credit risk and public and private banks are the fiscal situation of the federal government, the amount of public debt on its balance sheet, and the support provided by the government.

One of the benefits acquired by banks through government guarantees are subsidies 
with lower financing costs, which tend to decrease when the federal government is experiencing an economic crisis (Ejsing \& Lemke, 2011). In this context, Borensztein and Panizza (2009) believe that sovereign defaults affect banks within the country such that a downgrading of the government's financial situation increases the possibility of a bank crisis and/or downgrading of the risk level of the banks.

Table 6

\section{Results of Model 1 for the Bank Rating Downgrade vs Maintenance scenario}

\begin{tabular}{|c|c|c|c|c|c|c|}
\hline \multicolumn{7}{|c|}{ Panel A: Estimate that uses Cumulative Return as a Market Indicator } \\
\hline & \multicolumn{2}{|c|}{3 DAYS } & \multicolumn{2}{|c|}{5 DAYS } & \multicolumn{2}{|c|}{30 DAYS } \\
\hline Indicators & Coefficients & $\mathbf{P}>|\mathbf{z}|$ & Coefficients & $\mathbf{P}>|\mathbf{z}|$ & Coefficients & $\mathbf{P}>|\mathbf{z}|$ \\
\hline Cumulative Return & $7.228^{* *}$ & 0.037 & 2.875 & 0.418 & 3.482 & 0.144 \\
\hline $\begin{array}{l}\text { New Customer Loans / Customer } \\
\text { Deposits }\end{array}$ & -0.003 & 0.657 & -0.004 & 0.509 & -0.005 & 0.455 \\
\hline Return on Equity (ROE) & 0.011 & 0.803 & -0.004 & 0.918 & 0.009 & 0.856 \\
\hline Adjusted Net Equity & $-3.33 e-06$ & 0.652 & $3.78 \mathrm{e}-07$ & 0.962 & $-2.68 e-06$ & 0.748 \\
\hline $\begin{array}{l}\text { Allowance for Loan Losses / } \\
\text { Customer Loans }\end{array}$ & 0.006 & 0.965 & -0.011 & 0.940 & 0.011 & 0.940 \\
\hline Growth of Customer Credit & -0.015 & 0.204 & -0.013 & 0.247 & -0.017 & 0.151 \\
\hline GDP Growth & $-0.433^{* *}$ & 0.046 & $-0.411^{* *}$ & 0.040 & $-0.367^{*}$ & 0.079 \\
\hline N. Obs: & 79 & & 79 & & 79 & \\
\hline \multicolumn{7}{|c|}{ Panel B: Estimate that uses changes in Sovereign Risk or in Sovereign Risk Perspective as a Market Indicator } \\
\hline & \multicolumn{2}{|c|}{3 DAYS } & \multicolumn{2}{|c|}{5 DAYS } & \multicolumn{2}{|c|}{30 DAYS } \\
\hline Indicators & Coefficients & $P>|z|$ & Coefficients & $\mathbf{P}>|\mathbf{z}|$ & Coefficients & $\mathbf{P}>|\mathbf{z}|$ \\
\hline $\begin{array}{l}\text { Change in Sovereign Risk or } \\
\text { Sovereign Risk Perspective }\end{array}$ & 0.184 & 0.362 & -0.500187 & 0.173 & $-2.178^{* * *}$ & 0.000 \\
\hline $\begin{array}{l}\text { New Customer Loans / Customer } \\
\text { deposits }\end{array}$ & -0.004 & 0.529 & -0.0053027 & 0.466 & -0.013 & 0.205 \\
\hline Return on Equity (ROE) & -0.010 & 0.798 & -0.0106247 & 0.808 & 0.019 & 0.746 \\
\hline Adjusted Net Equity & $2.29 \mathrm{e}-06$ & 0.785 & $1.58 \mathrm{e}-06$ & 0.841 & $7.29 e-06$ & 0.501 \\
\hline $\begin{array}{l}\text { Allowance for Loan Losses / } \\
\text { Customer Loans }\end{array}$ & -0.022 & 0.871 & -0.0282172 & 0.854 & 0.009 & 0.958 \\
\hline Growth of Customer Credit & -0.012 & 0.297 & -0.0109755 & 0.352 & -0.023 & 0.134 \\
\hline GDP Growth & $-0.414^{* *}$ & 0.034 & $-0.3571767^{*}$ & 0.082 & -0.414 & 0.131 \\
\hline N. Obs: & 79 & & 79 & & 79 & \\
\hline${ }^{* * *} \mathrm{p}<0.01,{ }^{* *} \mathrm{p}<0.05,{ }^{*} \mathrm{p}<0.1$ & & & & & & \\
\hline
\end{tabular}

Source: Elaborated by the author.

As in the results for upgrades, the Cumulative Return indicators did not present any significant relationship regarding downgrading 5 days and 30 days before the announcement. For the 3-day period, Cumulative Return was significant at $95 \%$ reliability. This can be explained by stock market agent speculation during the period near the event of announcing a risk rating (Gropp, 2006).
The accounting indicators did not present a significant relationship with ratings downgrades, which might have happened due to the "too big to fail" theory mentioned by Distinguin, Hasan, and Tarazi (2013), where rating companies believe that the biggest banks are "too big to go bankrupt". However, we can notice that the GDP growth indicator is still significant at 99\% reliability for rating changes, whether these are 
downgrades or upgrades (Moody's, 2016; Fitch, 2015, Standard \& Poor's, 2011).

In general, the results analysis highlights that the market indicators Sovereign Risk and GDP Growth, when associated with the accounting indicators Asset Quality, Liquidity, Capital and Profitability, and Risk, can predict ratings changes in Brazilian banks, which is consistent with the results of Curry, Fissel, and Hanweck (2008) and Distinguin, Hasan, and Tarazi (2013).

The results also show that the market, in windows previous to bank ratings changes, did not price the ratings changes. In this case, it is clear that, unlike in the European and American scenarios, in windows previous to bank ratings changes stock market participants do not, on average, price ratings changes in uncertain and volatile environments, such as that of Brazil. Thus, this evidence suggests that sovereign risk and systemic-economic factors might be used as risk indicators in uncertain and volatile markets.

\section{Conclusion}

The objective of this study was to analyze if market indicators, as a complement to accounting indicators, can predict changes (upgrades or downgrades) in the risk ratings of banks in Brazil. Therefore, we used information gathered from a merger of two databases, Economática and Standard \& Poor's/Fitch, covering 2010 to 2014.

In this study, the sovereign rating and GDP growth in Brazil were important variables for predicting changes in the risk ratings of the banks. These variables associated with the accounting variables asset quality, liquidity, capital and profitability, and risk appetite of the banks were associated with changes in the risk ratings of the banks in Brazil.

The discussion contributes empirically to the literature regarding ratings changes of banks in countries with volatile financial markets, subject to political-economical uncertainties, and with frequent bank ratings changes. The result might be associated with the fact that Brazil has a smaller stock market, companies with concentrated control, a highly volatile market, and is subject to political and economic uncertainties.

This paper presents contributions for three groups: for investors, the research anticipates information that helps in purchasing, keeping, or selling bonds; for banks, it is important in presenting information that can be used to predict changes in risk and possible increases in fundraising costs; and, finally, for creditors, it is important because it indicates that in weak economies the financial system, regarding risks, is vulnerable to systemic changes in the country. Besides influencing investment, ratings changes can have an impact on future stock prices and on fundraising costs as well as on debt structure and market value.

\section{References}

Acharya, V., Drechsler, I., \& Schnabl, P. (2014). A pyrrhic victory? Bank bailouts and sovereign credit risk. The Journal of Finance, 69(6), 26892739.

Adams, M., Burton, B., \& Hardwick, P. (2003). The determinants of credit ratings in the United Kingdom insurance industry. Journal of Business Finance \& Accounting, 30(3-4), 539-572.

Adelino, M., \& Ferreira, M. A. (2016). Bank ratings and lending supply: Evidence from sovereign downgrades. Review of Financial Studies, 29(7), $1709-1746$.

Altman, E. I. (1968). Financial ratios, discriminant analysis and the prediction of corporate bankruptcy. The journal of finance, 23(4), 589-609.

Altman, E. I., \& Katz, S. (1976). Statistical bond rating classification using financial and accounting data. Proceedings of the Conference on Tropical Research in Accounting, 205-239.

Avkiran, N. K., \& Cai, L. C. (2012). Predicting bank financial distress prior to crises. In New Zealand Finance Colloquium, February. 
Berger, A. N., Davies, S. M., \& Flannery, M. J. (2000). Comparing market and supervisory assessments of bank performance: who knows what when? J Money Credit Bank, 32, 641-667.

Blume, M. E., Lim, F., \& MacKinlay, A. C. (1998). The declining credit quality of US corporate debt: Myth or reality? The journal of finance, 53(4), 1389-1413.

Bolton, P., \& Jeanne, O. (2011). Sovereign default risk and bank fragility in financially integrated economies. IMF Economic Review, 59(2), 162194.

Borensztein, E., \& Panizza, U. (2009). The costs of sovereign default. IMF Economic Review, 56(4), 683-741.

Bourguignon, F., Fournier, M., \& Gurgand, M. (2007). Selection Bias Corrections based on the Multinomial Logit Model: Monte Carlo Comparisons. Journal of Economic Surveys. 21(1), 174-205.

Braslin̦š, G̦., \& Arefjevs, I. (2013). Basel III: countercyclical capital buffer proposal: the case of Latvia. Journal of Business Management, 7, 5-15.

Correa, R., Lee, K. H., Sapriza, H., \& Suarez, G. A. (2014). Sovereign credit risk, banks' government support, and bank stock returns around the world. Journal of Money, Credit and Banking, 46(s1), 93-121.

Curry, T. J., Fissel, G. S., \& Hanweck, G. A. (2008). Equity market information, bank holding company risk, and market discipline. Journal of Banking \& Finance, 32(5), 807-819.

Demirgüç-Kunt, A., \& Detragiache, E. (2000). Monitoring banking sector fragility: a multivariate logit approach. The World Bank Economic Review, 14(2), 287-307.

Demirgüç-Kunt, A., \& Huizinga, H. (2013). Are banks too big to fail or too big to save? International evidence from equity prices and
CDS spreads. Journal of Banking \& Finance, 37(3), 875-894.

Distinguin, I., Hasan, I., \& Tarazi, A. (2013). Predicting rating changes for banks: how accurate are accounting and stock market indicators? Ann Finance, 9, 471-500.

Ejsing, J., \& Lemke, W. (2011). The Janus-headed salvation: Sovereign and bank credit risk premia during 2008-2009. Economics Letters, 110(1), 28-31.

Estrella, 2000. Credit ratings and complementary sources of credit quality information. Working Papers, 3. Basel Committee on Banking Supervision.

Fitch Ratings. (2015). Understanding the credit ratings: uses and limitations. Recovered on April $15^{\text {th }}, 2015$, from https://www.fitchratings.com. br/pages/def_rtg_about.

Firoz, C. M., Ansari, A. A., \& Akhtar, K. (2011). IFRS-Impact on Indian Banking Industry. International Journal of Business and Management, 6(3), 277-283.

Gaillard, N. (2014). What is the value of sovereign ratings? German Economic Review, 15(1), 208-224.

Gande, A., \& Parsley, D. C. (2014). Sovereign credit ratings, transparency and international portfolio flows. MPRA, 21118. Recovered on December $12^{\text {th }}, 2016$, from http://mpra.ub.unimuenchen.de/21118/

Gropp, R., Vesala, J. M., \& Vulpes, G. (2006). Equity and bond market signals as leading indicators of bank fragility. J Money Credit Bank, 38(2), 399-428.

Gullo, M. F. (2014). Agências de rating e os impactos de suas atividades sobre o sistema financeiro mundial. Working Papers. Boletim de Ciências Econômicas. Universidade de Coimbra. October. 
Hill, C A. (2004). Regulating the rating agencies. Georgetown University Law Center: Working Paper n. 452022, Washington University Law Quarterly, 82, 43.

Horrigan, J. O. (1966). Determination of longterm credit standing with financial ratios. Journal of Accounting Research, 4, 44-62.

Ioana, P. S. (2014). Credit Rating Agencies and Their Influence on Crisis. Annals of the University of Oradea, Economic Science Series, 23(2), 271-278.

Kaminsky, G., \& Schmukler, S. L. (2002). Emerging market instability: do sovereign ratings affect country risk and stock returns? The World Bank Economic Review, 16(2), 171-195.

Kaplan, R. S., \& Urwitz, G. (1979). Statistical model of bond ratings: a methodological inquiry. Journal of Business, 52(2), 231-262.

Krainer, J., \& Lopez, J. A. (2004). Incorporating equity market information into supervisory monitoring models. Journal of Money, Credit and Banking, 36(6), 1043-1067.

Lazarides, T. G., \& Drimpetas, E. (2015). Defining the Factors of Fitch Rankings in the European Banking Sector. Available at SSRN 2601248.

Li, H., Jeon, B. N., Cho, S. Y. \& Chiang, T. C. (2008).The impact of sovereign rating changes and financial contagion on stock market returns: Evidence from five Asian countries. Global Finance Journal, 19(1), 46-55.

Moody's. (2016). Metodologia de Rating: Bancos. New York. January.

Murcia, F. C. D. S., Dal-Ri Murcia, F., Rover, S., \& Borba, J. A. (2014). The determinants of credit rating: Brazilian evidence. BAR-Brazilian Administration Review, 11(2), 188-209.

Papaioannou, G. (2011). Economic and Market Factors versus Credit Rating Announcements, on Credit Default Swap Spreads. International Journal of Economics and Finance, 3(5), 42.

Pinches, G. E., \& Mingo, K.A. (1973). A multivariate analysis of industrial bond ratings. Journal of Finance, 28(1), 1-18.

Pinheiro, F. A. P., Savóia, J. R. F., \& Securato, J. R. (2015). Basileia III: Impacto para os Bancos no Brasil. Revista Contabilidade \& Finanças, 26(69), 345-361.

Pogue, T. F., \& Soldofsky, S. M. (1969). What's in a bond rating? Journal of Financial and Quantitative Analysis, 4(2), 201-228.

Sanfins, M. A. D. S., \& Monte-Mor, D. S. (2014). RiD: Uma Nova Abordagem para o Cálculo do Risco de Insolvência/(RiD: A New Approach to Estimate the Insolvency Risk). Revista Brasileira de Finanças, 12(2), 229.

Shen, C. H., Huang, Y. L., \& Hasan, I. (2012). Asymmetric benchmarking in bank credit rating. Journal of International Financial Markets, Institutions and Money, 22(1), 171-193.

Sinkey, J. R. (1975). A multivariate statistical analysis of the characteristics of problem banks. Journal of Finance. 30(1), 21-36.

Standard \& Poor's. (2009). Entendendo as definiçóes de ratings da Standard \& Poor's. New York, 2009.

Standard \& Poor's. (2011). Bancos: Metodologia e Premissas de Rating. New York, 2011.

Standard \& Poor's. (2014). Top Brazilian banks. New York, 2014.

Standard \& Poor's. (2016). Brazil outlook revised to negative. New York.

West, R. R. (1970). An alternative approach to predicting corporate bond ratings. Journal of Accounting Research, 8(1), 118-127. 


\section{About the Authors:}

1. Ronaldo Trapiá Garcia, Master em Accounting, Fucape Business School, Brazil.

E-mail: ronaldotrapia@bb.com.br

\section{ORCID}

(i) 0000-0003-1283-2464

2. Danilo Soares Monte-Mor, PhD. in Accounting and Administration, Fucape Business School, Brazil. E-mail: danilo@fucape.br

ORCID

(iD) $0000-0002-5677-5804$

3. Neyla Tardin, PhD. in Accounting and Administration, Fucape Business School, Brazil.

E-mail: neyla@fucape.br

ORCID

(iD) 0000-0002-8906-3942

\section{Contribution of each author}

\begin{tabular}{|c|c|c|c|}
\hline Contribution & Ronaldo Trapiá Garcia & Danilo Soares Monte-Mor & Neyla Tardin \\
\hline 1. Definition of research problem & $\sqrt{ }$ & $\sqrt{ }$ & \\
\hline $\begin{array}{l}\text { 2. Development of hypotheses or research questions } \\
\text { (empirical studies) }\end{array}$ & $\sqrt{ }$ & $\sqrt{ }$ & \\
\hline 3. Development of theoretical propositions (theoretical Work) & & $\sqrt{ }$ & \\
\hline 4. Theoretical foundation/ Literature review & $\sqrt{ }$ & & \\
\hline 5. Definition of methodological procedures & & $\sqrt{ }$ & \\
\hline 6. Data collection & $\sqrt{ }$ & & \\
\hline 7. Statistical analysis & & $\sqrt{ }$ & $\sqrt{ }$ \\
\hline 8. Analysis and interpretation of data & & $\sqrt{ }$ & $\sqrt{ }$ \\
\hline 9. Critical revision of the manuscript & & $\sqrt{ }$ & \\
\hline 10. Manuscript Writing & $\sqrt{ }$ & & $\sqrt{ }$ \\
\hline
\end{tabular}

